\title{
Eight years of experience with biological treatment in juvenile idiopathic arthritis
}

\author{
A F Mourão ${ }^{1,2^{*}}$, A Rodrigues ${ }^{3,2}$, F Vinagre ${ }^{4}$, E Sousa ${ }^{3,2}$, J Polido-Pereira ${ }^{3,2}$, C Macieira ${ }^{3}$, F Ramos $^{3}$, J Costa ${ }^{3}$, \\ J Gomes Pedro ${ }^{5}$, J Pereira da Silva ${ }^{3}$, J E Fonseca ${ }^{3,2}$, M J Santos ${ }^{4,2}$, H Canhão $0^{3,2}$ \\ From 5th European Workshop on Immune-Mediated Inflammatory Diseases \\ Sitges-Barcelona, Spain. 1-3 December 2010
}

\section{Introduction}

The introduction of biological agents has provided a new therapeutic approach to the treatment of juvenile idiopathic arthritis (JIA).

\section{Aim}

To analyze the data from a eight year follow-up of JIA patients treated with biological agents.

\section{Methods}

Patients with JIA who started a biological treatment were enrolled in a prospective observational study. Clinical and laboratory data were recorded at baseline and every 3 months.

\section{Results}

24 patients, $54 \%$ female, mean age at disease onset $7 \pm 4$ years, mean disease duration $11 \pm 8$ years. $25 \%$ had systemic arthritis, $25 \%$ rheumatoid factor (RF) positive polyarthritis, $17 \%$ RF negative polyarthritis, $12 \%$ enthesitis-related arthritis, and the remaining $21 \%$ were equally distributed across the other groups. All patients had been previously treated with at least one DMARD. The indication for biological treatment was DMARD failure in $86 \%$ of the cases and MTX toxicity in the remaining $14 \%$.

Biological treatment was started at a mean age of $15 \pm$ 7 years and maintained for a mean of three years ( 2 months- 7 years). 20 patients received etanercept, 3 infliximab and 1 anakinra as first-line biological. All patients experienced a significant reduction in all disease activity parameters at 3 months with maximum improvement at six months (reduction in active joint count of $92 \%$, joints with limited range of motion $81 \%$,

${ }^{1}$ Rheumatology Dept., Egas Moniz Hospital, Lisbon, Portugal

Full list of author information is available at the end of the article
VAS $35 \%$, ESR of $61 \%$, CRP $88 \%(\mathrm{p}<0.05))$. This response was sustained up to 7 years of treatment in $75 \%$ of the patients. The remaining $25 \%$ switched to a second biological due to loss of efficacy.

\section{Conclusion}

Biological treatment was an effective and safe therapeutic option in this cohort of patients with severe JIA refractory or intolerant to classic DMARDs.

\section{Author details}

${ }^{1}$ Rheumatology Dept., Egas Moniz Hospital, Lisbon, Portugal. '2Rheumatology Research Unit, Instituto de Medicina Molecular, Lisbon, Portugal. ${ }^{3}$ Rheumatology Dept., Santa Maria Hospital, Lisbon, Portugal. ${ }^{4}$ Rheumatology Dept., Garcia de Orta Hospital, Almada, Portugal. ${ }^{5}$ Pediatrics Dept., Santa Maria Hospital, Lisbon, Portugal.

Published: 25 November 2010

\section{doi:10.1186/1479-5876-8-S1-P64}

Cite this article as: Mourão et al:: Eight years of experience with biological treatment in juvenile idiopathic arthritis. Journal of Translational Medicine 2010 8(Suppl 1):P64.

Submit your next manuscript to BioMed Central and take full advantage of:

- Convenient online submission

- Thorough peer review

- No space constraints or color figure charges

- Immediate publication on acceptance

- Inclusion in PubMed, CAS, Scopus and Google Scholar

- Research which is freely available for redistribution 